\title{
Restorative Justice: Paradigma Baru Peradilan Pidana
}

\author{
$\mathrm{H}$ ariman Satria
}

DATA NASKAH

Masuk: 11 Agustus 2017

Diterima: 2 Februari 2018

Terbit: 1 Juni 2018

KORESPONDEN PENULIS:

Fakultas Hukum Universitas Muhammadiyah Kendari. JIn. KH Ahmad Dahlan No. 10 Kendari, 93118. Email:

hariman85antikorupsi@gmail.com

\begin{abstract}
Direction of criminal justice in Indonesia is currently experiencing a shift from retributive to restorativerehabilitative or daad-dader-strafrecht or model of balance of interests. This is confirmed by Laws N umber 11 of 2012 on Juvenile Justice System, which states in A rticle 6 to A rticle 8 that emphasizes the concept of restorative justice through diversion. B oth of these concepts allow the settlement of children out of the criminal justice. H owever, not all criminal offenses committed by children can be settled out of court (diversion) unless two conditions are met: imprisonment for a criminal offense under seven years and is not a repetition of criminal offenses (recidivism). The essences of restorative justice are three. First, in the settlement of children, it is necessary that the offenders and their families and victims and their families can sit together to discuss the settlement of issues including reparations to victims (restitution in integrum). Second, the essence of restorative justice is to give punishment to the offenders but the punishment is didactic, in order to benefit to both of the perpetrator and the victims. This is in line with an adagio "delinquens per iram provocatus puniri debet mitius". Third, regulation of a quo using two approaches which are victims and offenders mediation approaches as implemented in $\mathrm{N}$ orth A merica as well as approach that emphasizes restitution and reparation (court based restitutive and reparative measure), as practiced in the $U$ nited $\mathrm{K}$ ingdom.
\end{abstract}

K eywords: Restorative Justice, C riminal Justice.

\begin{abstract}
ABSTRAK
A rah peradilan pidana di Indonesia pada saat ini men gal ami pergeseran dari retributif ke restoratif-rehabilitatif atau daad-dader-strafrecht atau model keseimbangan kepentingan. $\mathrm{H}$ al ini terkonfirmasi melalui U ndangU ndang N o. 11 Tahun 2012 tentang Sistem Peradilan Pidana Anak, yang dalam Pasal 6 jo Pasal 8 menekankan pada konsep keadilan restoratif melalui diversi. Kedua konsep ini memungkinkan penyelesaian perkara anak ke luar peradilan pidana. Namun demikian tidak semua tindak
\end{abstract}


pidana yang dilakukan oleh anak dapat diselesaikan di luar pengadilan (diversi) kecuali terpenuhi dua syarat yaitu tindak pidana diancam pidana penjara di bawah tujuh tahun dan bukan merupakan pengulangan tindak pidana (residivis). Inti dari keadilan restoratif yaitu: Pertama, dalam penyelesaian perkara anak diupayakan agar pelaku dan keluarganya serta korban dan keluarganya dapat duduk bersama untuk membicarakan penyelesaian masalah termasuk pemulihan kepada korban (restitution in integrum). K edua, keadilan restoratif hakikatnya adalah memberi hukuman kepada pelaku tetapi hukuman tersebut bersifat mendidik sehingga memberi manfaat baik kepada pelaku maupun korban. $\mathrm{Hal}$ ini sejalan dengan adugium delinquens per iram provocatus puniri debet mitius. Ketiga, peraturan a quo menggunakan dua pendekatan yakni pendekatan mediasi korban dan pelaku (victim offender mediation) seperti yang diterapkan di Amerika U tara serta pendekatan yang menekankan pada ganti kerugian dan pemulihan (court based restitutive and reparative measure), seperti yang dipraktikan di Inggris.

K ata K unci: Restorative Justice, Peradilan Pidana.

\section{PENDAHULUAN}

Bila dilihat dari temanya maka tulisan ini pusarannya terletak dua hal penting yaitu pertama, penegakan hukum - peradilan pidana. Kedua, keadilan restoratif. Dengan kata lain rasio logis yang hendak dipaparkan dalam tulisan ini adalah seputar peradilan pidana. Berbicara tentang peradilan pidana tidaklah dapat dilepaskan dari penegakan hukum (law enforcement). Sebab dalam konteks penegakan hukum secara eksplisit terkandung proses peradilan pidana. Sedangkan proses peradilan pidana hulunya adalah hukum acara pidana atau hukum pidana formil, yang dalam pembacaan Hazewinkel Suringa disebut sebagai jus puniendi adalah hak negara untuk menuntut pidana, hak untuk menjatuhkan pidana dan hak untuk melaksanakan pidana (Hamzah, 2012:4). M enurut Leo Polak, hak negara dalam jus puniendi ini dilaksanakan oleh aparatnya. Karena itu hanya yang mempunyai hak memerintah yang dapat membuat kehendaknya dituruti dan berhak menjatuhkan pidana (Utrecht, 1986:150).

Masih mengenai jus puniendi, van Bemmelen menguraikan bahwa ilmu hukum acara pidana (jus puniendi) mempelajari peraturan-peraturan yang diciptakan oleh negara karena adanya dugaan terjadi pelanggaran undangundang hukum pidana (Atmasasmita, 2010:1). Dalam kosa kata lain kehadiran hukum acara pidana disebabkan oleh pelanggaran terhadap hukum pidana materil (jus peonale). Hubungan ini kemudian dielaborasi lebih jauh oleh Moeljatno dengan mendefinisikan hukum pidana dalam tiga bagian penting yakni pertama, menentukan perbuatan-perbuatan mana yang tidak boleh dilakukan, dilarang, dengan disertai ancaman atau sanksi yang berupa pidana tertentu bagi barang siapa melanggar larangan tersebut. Kedua, menentukan kapan dan dalam hal apa kepada mereka yang telah melanggar larangan-larangan itu dapat dikenakan atau dijatuhi pidana sebagaimana yang telah diancamkan. Ketiga, menentukan dengan cara bagaimana pidana itu dapat dilaksanakan apabila ada orang yang disangka telah melanggar larangan tersebut (M oeljatno, 2008:1).

Dalam bayangan penulis, merujuk pada argumentasi M oeljatno tersebut, hukum pidana terbagi menjadi dua bagian, yaitu hukum pidana materil dan hukum pidana formil. Hukum pidana materil berkaitan dengan poin pertama dan kedua (perbuatan yang tidak boleh dilakukan, dilarang, yang disertai ancaman pidana bagi barang siapa yang melakukan), sedangkan hukum pidana formil berkaitan dengan poin ketiga (dalam hal apa kepada mereka yang telah melanggar larangan itu dapat dikenakan sanksi pidana dan dengan cara bagaimana pengenaan pidana itu dapat dilaksanakan). Pendeknya pada butir pertama dan kedua, Moeljatno melukiskan inwal perbuatan pidana yang ditetapkan dalam hukum pidana materil (jus peonale), termasuk ancaman sanksi (penitentaire recht) sedangkan poin ketiga adalah berkenaan dengan pertanggungjawaban pidana melalui hukum pidana formil (jus puniendi). Atas gagasan yang dikemukakan oleh Hazewinkel Suringa, van Bemmelen, Leo Polak dan Moeljatno tersebut maka kita dapat mengatakan bahwa hukum pidana pada dasarnya terbelah dua yakni hukum pidana meteril (jus peonale) dan hukum pidana formil (jus puniendi). Keduanya adalah satu kesatuan yang tidak terpisah-pisahkan satu sama lain.

Secara legal normatif hukum acara pidana di Indonesia diatur dalam Undang-Undang Nomor 8 Tahun 1981 tentang 
Kitab Undang-Undang Hukum Acara Pidana (KUHAP). Berdasarkan peraturan a quo kewenangan penegakan hukum dilaksanakan oleh kepolisian, kejaksaan dan pengadilan pada semua tingkatannya. Institusi-institusi hukum inilah yang berwenang meneyelenggarakan proses peradilan pidana, sejak tahap penyidikan hingga tahap putusan di pengadilan. Namun demikian akhir-akhir ini seiring perkembangan zaman, kita dapat menemukan proses peradilan pidana yang berbeda dengan KUHAP. Dalam kosa kata lain terdapat peraturan perundang-undangan yang mengatur sendiri (lex specialis) ketentuan beracaranya termasuk penyelenggara peradilan pidananya. Salah satu peraturan yang menarik dicermati dan didiskusikan adalah Undang-Undang Nomor 11 Tahun 2012 tentang Sistem Peradilan Pidan Anak (SPP Anak). Peraturan a quo memiliki kekhasan bila dibandingkan dengan KUHAP, bahkan boleh dikatakan memperkenalkan pranata hukum baru dalam peradilan pidana yakni diversi dan keadilan restoratif (restorative justice). Suatu konsep yang berkembang yang melibatkan korban di dalamnya disebut restorative justice (Widowaty dan Fitriyanti, 2014: 3).

Konsep diversi dan restorative justice tersebut adalah konsep hukum yang sejak KUHAP diberlakukan tidak dikenal, tetapi pembentuk undang-undang menyadari sepenuhnya bahwa harus ada pembedaan pendekatan dalam proses peradilan pidana pada subjek-subjek atau adresat tertentu, seperti anak. Hal ini terkonfirmasi jika membaca dan memahami bagian menimbang peraturan a quo. Pertama, bahwa anak merupakan amanah dan karunia Tuhan Yang Maha Esa yang memiliki harkat dan martabat sebagai manusia seutuhnya. Kedua, untuk menjaga harkat dan martabatnya, anak berhak mendapatkan perlindungan khusus terutama perlindungan hukum dalam sistem peradilan. Ketiga, Indonesia sebagai negara pihak dalam Konvensi Hak-Hak Anak (Convention on the Right of the Child) yang mengatur prinsip perlindungan hukum terhadap anak mempunyai kewajiban untuk memberikan perlindungan khusus terhadap anak yang berhadapan dengan hukum. Keempat, Undang-Undang Nomor 3 Tahun 1997 tentang Pengadilan Anak sudah tidak sesuai lagi dengan perkembangan dan kebutuhan hukum masyarakat karena belum secara komprehensif memberikan perlindungan kepada anak yang berhadapan dengan hukum sehingga perlu diganti dengan undang-undang yang baru.

Singkat kata, konsep keadilan restoratif yang ditempuh melalui diversi dalam peradilan anak adalah sebagai upaya untuk memberikan perlindungan hukum kepada anak yang sedang menghadapi masalah hukum. Perlindungan hukum yang dimaksud adalah penyelesaian perkara anak dari proses peradilan pidana, ke proses di luar peradilan pidana (Pasal 1 butir 1 UU SPP Anak). Dengan demikian kepada anak yang melakukan tindak pidana paradigma peradilannya berubah, semula diposisikan sebagai pelaku kejahatan seperti pada umumnya, tetapi melalui peraturan a quo - menempatkan peradilan anak berbeda dengan orang dewasa. Anak yang melakukan tindak pidana hanya dianggap tersesat (anak nakal) sehingga perlu direhabilitasi. Hukuman terhadap anak yang melakukan tindak pidana harus lebih ringan dibandingkan dengan orang dewasa. Hal ini sejalan dengan adugium delinquens per iram provocatus puniri debet mitius.

Intinya peradilan pidana mengakomodasi tujuan pemidanan dari retributif ke restoratif. Dari pembalasan ke pemulihan atau gantu kerugian. Ide dasar inilah yang menjadi stimulan dalam peraturan a quo. M eskipun harus dikatakan juga, bahwa tidak semua tindak pidana yang dilakukan oleh anak dapat dikenakan diversi atau restorative justice. Paling tidak ada dua sayarat yang harus dipenuhi bila merujuk pada Pasal 7 ayat (2) UU SPP Anak, yakni pertama, perbuatan pidananya diancam pidana di bawah 7 (tujuh) tahun. Kedua, bukan pengulangan tindak pidana (residivis). Tegasnya baik diversi maupun restorative justice adalah pranata baru dalam peradilan pidana Indonesia sehingga membutuhkan kajian lebih lanjut dan komprehensif. Atas dasar itulah penulis menuliskan gagasan yang sederhana ini.

\section{RUMUSAN MASALAH}

Bagaimanakah kedudukan restorative justice bila dilihat dari optik peradilan pidana Indonesia?

\section{PEMBAHASAN}

\section{Sistem Peradilan Pidana}

Berbicara tentang sistem peradilan pidana tidaklah mungkin dilepaskan dari hukum acara pidana. Keduanya adalah berkaitan erat dengan sistem hukum yang berlaku di 


\section{MEDIA
HUKUM}

sebuah negara. Hal ini adalah suatu kewajaran sebab sistem peradilan pidana adalah sebagai salah satu sub sistem dari sistem hukum nasional secara keseluruhan yang dianut oleh suatu negara. Oleh sebab itu, setiap negara di dunia ini mempunyai sistem peradilan pidana yang meskipun secara garis besar hampir sama namun memiliki karakter tersendiri yang disesuaikan dengan kondisi sosial masyarakat, budaya dan politik yang dianut (Atmasasmita, 2010:4). Lawrence F. Travis III menyebut sistem peradilan pidana sebagai the integrited criminal justice system begins with the detection of crime, proceeds through investigation, arrest, initial appearence before the court, charging (arraingment), trial, sentencing, and posible revocation, and ends with discharge (Travis, 2012:37). Jadi sistem peradilan pidana dimulai sejak tahap penyelidikan, penyidikan, penahanan, penuntutan, pemeriksaan sidang pengadilan hingga tahap pelaksanaan hukuman. Dengan demikian lingkup sistem peradilan pidana bermula dari kepolisian, kejaksaan, pengadilan hingga lembaga pemasyarakatan.

Tidak jauh berbeda dengan argumentasi Travis III inwal sistem peradilan pidana adalah dikemukakan oleh M ardjono Reksodiputro yang mengatakan bahwa sistem peradilan pidana merupakan sistem pengendalian kejahatan yang terdiri dari lembaga-lembaga kepolisian, kejaksaan, pengadilan dan pemasyarakatan (Reksodiputro, 1993:1). Gagasan Marjono ini kelihatanya masih melihat aparat penegak hukum sebagai bagian dari pencegahan kejahatan - perbuatan pidana, padahal dalam konteks sistem peradilan pidana tidak lagi berbicara tentang pencegahan atau pengendalian kejahatan, tetapi penegakan hukum yang diakibatkan oleh suatu perbuatan pidana melalui pendekatan sistem. Intinya sistem peradilan pidana bekerja ketika telah terjadi perbuatan pidana bukan sebaliknya.

Merujuk pada argumentasi Travis III dan Marjono Reksodiputro tersebut kita dapat mengatakan bahwa perspektif sistem peradilan pidana, tidak hanya mencakup satu institusi tetapi berkaitan erat dengan beberapa institusi negara yang menurut Feeney pekerjaan aparat penegak hukum yang satu akan memberikan dampak dan beban kerja kepada aparat penegak hukum yang lain. Feeney kemudian menegaskan, what once criminal justice agency does likely to affect and be affected by other agencies and a detailed knowledge of the kinds of interactions that are likely to take is essential for undertaking system improvement (Hiariej, 2010:7). Oleh karan itu M ichael Cavadino dan James Dignan menyebut sistem peradilan pidana sebagai a term covering all those institution which respond officially to the commission of offences, notably the police, prosecution authorities and the court (Hiariej, 2010:7). Tegasnya sistem peradilan pidana dimulai dari kepolisian, kejaksaan dan akhirnya di pengadilan.

M asih mengeni sistem peradilan pidana, dalam sistem hukum anglo saxon dikenal dua terminologi yakni criminal justice process dan criminal justice system, keduanya diyakini terdapat perbedaan satu sama lain. Criminal justice process berkenaan dengan proses kepada pelaku kejahatan yang dimulai pada tahap penyelidikan, sampai pelaku dihadapkan si sidang pengadilan. Ditegaskan oleh Joshua Dressler, criminal justice process is specialis commonly the investigatory offender before adjudicatory (Dressler, 2002:362). Sedangkan criminal justice system dipandang sebagai hubungan keputusan antara lembaga dalam peradilan pidana. Secara gamblang disampaikan oleh Sanford H. Kadish, the criminal justice system may be integrated in examining particular phases of criminal justice (investigation-prosecution-ajudicative) and in interpreting the system as a whole (Kadish, 1983:450).

Penjelasan lebih jauh tentang sistem peradilan pidana dikemukakan oleh Hebert L. Packer. la berkata that integrited criminal justice system, I call these two models the due process model and the crime control model. Crime control model is based on the proposition that the repression of criminal conduct is by far the most important function to be performed by the criminal process. Crime control model values are effiency, speed and finalty. Than due process model in this concept of legal guilt lies the explanation for the apprently quixotic persumption of innosence of wich we spoke earlier. A man who, after police investigation is charged with having commited a crime can hardly be said tobe presumptively innocent, if what we mean is factual innosence (Packer, 1968:151-153).

Dengan demikian dalam optik Packer sistem peradilan pidana tedapat dua model yakni crime control model dan due process model. Crime control model memiliki 5 (lima) 
karakteristik berupa: represif, efisiensi, presumption of guilt, factual guilt dan informal fact finding. Sedangkan due process model juga memiliki 5 (lima) karakteristik berupa: efektivitas, legal guilt, presumption of innocent, formal adjudicative dan preventive. Dalam crime control model secara implisit mengutamakan kecepatan sehingga tingkah laku kriminal harus segera ditindak dan si tersangka dibiarkan sampai ia sendiri yang melakukan perlawanan. Sedangkan dalam due process model diibaratkan seperti orang yang sedang melakukan lari gawang. Intinya kedua model tersebut ada nilai-nilai yang bersaing tetapi tidak berlawanan.

Packer mendikotomikan sistem peradilan pidana dalam dua kategori tersebut, didasari oleh suatu fakta bahwa ada perbedaan yang signifikan dalam pelaksanaan proses kriminal. Karena itu kata Packer ada semacam ciri mendasar yang dapat membedakan antara crime control model dan due process model. First, the crime control model to the emphasize this adversary aspek of the process. The due process model tends to make it central. Second, in order to achieve this high purpose, the criminal model requirs that primary attention be pain to the efficiency with wich the criminal process operates to scren suspects determine guilt and secure appropriate dispositions of prosoon convicted of crime. Third, if the crime control model resembles an assembely line. The due process model look very much like an abstacle course. Fourth, the persumption of guilt, as it operates in the crime control model (Packer, 1968:165170).

Kontestasi gagasan yang dikembangkan oleh Packer tersebut kemudian dilengkapi oleh M ichael King dengan menambahkan empat model lain yaitu medical model, bureaucratic model, status pasage model dan power model (Hiariej, 2010:5). Dalam medical model proses acara pidana diibaratkan seperti mengobati orang sakit. Ditegaskan oleh King, the restoration of the defendant to a state of mental and social health whereby s/he will be able to cope with the demands society makes oh him/her and refrain from the conduct which causes further intervention to be necessary. Bureaucratic model memandang sistem peradilan pidana sebagai konflik antara negara dan terdakwa. Dikatakan demikian karena dengan aturan yang terbatas dalam beracara dan pembuktian, negara bebas memilih untuk membuat putusan kendatipun terkadang meniadakan kejadian yang sesunggunya (Hiariej, 2010:5).

Selanjutnya adalah status passage model. Model ini memandang sistem peradilan pidana sebagai suatu proses penerimaan status bagi si terpidana oleh masyarakat yang diwakili pengadilan. Ihwal status passage model ini, King berujar, this perspective stresses the function of the criminal court as institutions for denouncing the defendant, reducing his social status and promoting solidarity within the community (Hiariej, 2010:6). Terakhir adalah power model yang menekankan bahwa sistem peradilan pidana adalah instrumen dari (ruling class) golongan berkuasa yang melakukan diskriminasi terhadap kelompok-kelompok tertentu termasuk di dalamnya kelompok etnis minoritas. Sistem peradilan pidana adalah untuk melindungi golongan yang berkuasa kendatipun terdapat perbedaan antara das sollen dan das sein (Hiariej, 2010:6).

Atas pembedaan sistem peradilan pidana baik yang dikemukakan oleh Packer maupun King tersebut, Ben Emmerson, Andrew Ashworth dan Alison Macdonald mengatakan bahwa itu semua merupakan pembedaan yang klasik dalam sistem peradilan pidana. Pembedaan kedua model ini merupakan hasil konflik antara pemikiran konservatif dan liberal atau antara punishment dan rehabilitation. Pemikiran konservatif menekankan pada pentingnya memberikan hukuman kepada pelaku sebagai balasan atas kejahatan yang dilakukan. Sedangkan pemikiran rehabilitation beranggapan bahwa meskipun pelaku kejahatan telah melanggar hukum tetapi ia diibaratkan sebagai orang yang tersesat sehingga harus direhabilitasi (Emmerson, Asworth dan Macdonald, 2007:692). Dalam kosa kata lain, sesungguhnya hanya ada satu model peradilan pidana, kata John Graffit yakni the battle model. Model ini digambarkan sebagai pertentangan atau pertarungan antara terdakwa melalui kuasa hukumnya melawan negara melalui aparatnya (Joyce, 2006:476).

Pendapat senada dikemukakan oleh Muladi, yang mengkritik secara tajam keberadaan crime control mode dan due process model. M enurut Muladi, crime control model tidak cocok diterapkan sebab mengutamakan tindakan yang bersifat represif sehingga dikhawatirkan berpotensi melanggar HAM, padahal hukum pidana lahir 
dengan tujuan mencegah kesewenang-wenangan negara kepada warganya. Dengan kata lain melindungi HAM warga negara. Sedangkan due process model juga tidak sepenuhnya menguntungkan karena bersifat anti-authoritarian values. Model yang cocok digunakan khususnya di Indonesia adalah yang mengacu kepada daad-dader strafrecht atau model keseimbangan kepentingan. Model ini lebih realistik karena memperhatikan berbagai kepentingan yang harus dilindungi oleh hukum pidana yaitu kepentingan negara, kepentingan individu, kepentingan umum, kepentingan pelaku dan kepentingan korban kejahatan (Muladi, 1995:15).

Kembali pada pembagian sistem peradilan pidana yang dikembangkan oleh Packer dan King, dalam perkembangannya King menempatkan model-model sistem peradilan pidana tersebut dalam dua pendekatan, yakni participant approaches dan social approaches. Participant approaches adalah sistem peradilan pidana dilihat dari sudut pandang aparat penegak hukum, meliputi 3 model, yakni crime control model, due process model dan medical model. Sedangkan social ap proaches adalah sistem peradilan pidana dilihat dari sudut pandang masyarakat yang mencakup bureaucratic model, status passage model dan power model. M enurut King, dalam participant approach, ketiga model pertama tersebut telah mengidentifikasi berbagai nilai dalam proses acara pidana dan aparat penegak hukum diberi kebebasan untuk memilih mana yang akan digunakan. Ketiga model tersebut tidak ada satu model pun mengungguli yang lain, semuanya memiliki kelebihan masing-masing (Hiariej, 2010:7).

Beradasarkan uraian tentang sistem peradilan pidana tersebut, bila dihubungkan dengan hukum acara pidana di Indonesia, maka dapat dikemukakan beberapa hal. Pertama, hukum acara pidana Ind onesia pada dasannya tidak megenal integrated criminal justice system yang diungkapkan baik oleh Packer maupun King. Dalam KUHAP secara intrinsik telah ditetapkan kewenangan masing-masing aparat penegak hukum, misalnya polisi sebagai penyidik, jaksa sebagai penuntut dan hakim sebagai pemutus perkara pidana. Dengan kata lain kita menggunakan asas diferensiasi fungsional (Satria, 2012:68). Artinya, masing-masing aparat penegak hukum mempunyai tugas sendiri-sendiri dan terpisah satu sama lain. Kedua, model yang dikemukakan oleh Muladi, pada dasarnya relevan dan realistis bila dikorelasikan dengan perkembangan hukum pidana dan hukum acara pidana akhir-akhir ini. Harus diakui bahwa KUHAP kita masih terlelu offender oriented padahal penderitaan korban jauh lebih dahsyat dan membutuhkan perhatian serius dari negara. Artinya belum seimbang perlakuan negara kepada pelaku dan korban kejahatan.

Ketiga, inwal crime control model dan due process model, keduanya tidak dianut secara ketat dalam praktik peradilan pidana kita. Pada satu sisi cenderung pada crime control model, namun di sisi lain kelihatannya berkombinasi dengan due process model. Sebagai contoh, asas presumption of innocent tetap menjadi landasan normatif aparat penegak hukum ketika memeriksa tersangka. Artinya, tersangka tetap dianggap tidak bersalah sampai ada putusan pengadilan yang inkracht. Tetapi secara formal KUHAP menegaskan dalam Pasal 17 bahwa penangkapan dan penahanan dilakukan terhadap seseorang yang "diduga keras" melakukan suatu tindak pidana. Itu artinya aparat penegak hukum pada akhirnya menggunakan prinsip presumption of guilt. Prinsip ini adalah salah satu ciri dari crime control model.

\section{Memahami Restorative Justice}

James Dignan menguraikan sisi historis keadilan restoratif (restorative justice), dengan mengatakan bahwa the term restorative justice is ussualy attributed to Albert Eglash (1977), who sought to differentiate between what he saw as three distinct forms of criminal justice. The first is concerned with "retributive justice", in wich the primary emphasis is on punishing offender for what they have done. The second relates to what he called "distributive justice" in wich the primary emphasis is on the rehabilitation of offenders. The third is concerned with "restorative justice", which he broadly equated with the principle of restitution (Dignan, 2005:94). Karena itu pembicaraan tentang restorative justice tidak dapat dilepaskan dari seorang yang bernama Albert Eglash yang pada tahun 1977 membagi tiga kategori peradilan pidana yakni retributive justice, distributive justice dan restorative justice. Singkatnya konsep restorative justice pertama kali diperkenalkan oleh Albert 
Eglash.

Namun demikian jauh sebelum Albert Eglash mengemukakan gagasannya, peradaban dan tradisi Arab Kuno, Yunani, Romawi Kuno dan Hindustan sebetulnya telah mengenal keadilan restoratif khusus dalam kejahatan penghilangan nyawa. Meskipun pada saat itu tidak menggunakan istilah keadilan restoratif tetapi paling tidak terdapat pendekatan restoratif. Demikian pula di kalangan masyarakat Budha, Tao dan Konfusius yang jauh-jauh hari telah mendorong keadilan restoratif dalam menyelesaikan masalah hukum mereka, melalui semboyan "he who atones is forgiven" artinya dia yang menebus, diampuni. Ditegaskan oleh John Braithwaite, restorative justice it grounding in traditions of justice from the ancient Arab, Greek, and Roman civilization, Indian Hindus, Taoist, and Confucian that accepted a restorative approach even to homicide, for whom "he who atones forgiven" (Braithwaite, 1998:323).

Wesley Cragg mengaitkan kemunculan restorative justice dengan teori retributif atau pembalasan dalam hukum pidana. M enuut Cragg teori pembalasan pada dasarnya kurang begitu berhasil dalam menekan terjadinya kejahatan. Lebih parahnya lagi tidak mampu memperbaiki kerugian yang diderita oleh korban. Karena itu ada sebuah upaya untuk mengubah paradigma pemidanaan dari pembalasan menuju restoratif atau pemulihan (Cragg, 1992:138-140). Dalam perkembangannya konsep restorative justice tersebut terus berevolusi dengan berbagai istilah dan menjadi model yang dominan dalam peradilan pidana pada sebagian besar sejarah umat manusia dari segala bangsa (Braithwaite, 1998:324). Demikian pula John Braithwaite menyebut bahwa restorative justice pada awalnya dianggap sebagai model alternatif yang ditujukan untuk peradilan anak. Dikatakan demikian karena model ini menitikberatkan pada keadilan dan kesejahteraan atau antara antara rehabilitasi dan retribusi (Braithwaite, 2002:10). Menghukum pelaku kejahatan adalah penting dilakukan tetapi tidak boleh melupakan upaya perbaikan pada mental pelaku. Atas gagasan ini Kathleen Daly menyebut restorative justice is a set of ideals about justice the assumes a generous, emphatetic, supportive, and rational human spirit (Sullivan dan Tifft, 2006:134).
Joanna Shapland dengan mengutip argumentasi Marshall mend efinsikan restorative justice sebagai process whereby all the parties with a stake in a particular offence come together to resolve collectively how to deal with the aftermath of the offence and its implication for the future (von Hirsch, et.all, 2003:197). Keadilan restoratif adalah sebuah proses dimana para pihak (pelaku-korban) yang terlibat dalam kejahatan secara bersama-sama mengatasi tindakan tersebut termasuk menyelesaikan dampaknya di masa mendatang. Wayne R. LaFave menempatkan keadilan restoratif sebagai bagian dari teori pemidanaan. LaFave kemudian mengatakan, restorative justice its said, creates an avenue to bring criminals and their victims together rather than keep them apart (LaFave, 2010:27). Dengan demikian keadilan restoratif adalah berusaha membawa pelaku dan korban kejahatan agar secara bersama-sama membahas penyelesaian masalah mereka.

Tegasnya kata Joshua Dressler, retorative justice emphasizes the importance of elevating the role of crime victims and community members, holding offender directly accountable to the people they have violeted, restoring the emotional and material losses of victims, and providing a range of opportunities for dialogue, negotiation, and problem solving, which can lead to a greater sense of community safety, conflict resolution, and closure for all involved (Drassler, 2002:1333). Jadi keadilan restotratif menekankan pada pentingnya peran korban dan anggota masyarakat untuk mendorong pelaku agar bertanggungjawab kepada korban, memulihkan kerugian emosional dan material korban, mendorong dialog atau negosiasi untuk menyelesaikan masalah yang telah terjadi sehingga dapat menyelamatkan masyarakat dari konflik berkepanjangan.

Berkenaan dengan itu, Bazemore dan Walgrave kemudian mengemukakan tiga prinsip dalam keadilan restoratif. First, it would seek to ensure that all parties are treated with equity, meaning that they and others in similar circumtances will feel that they are treated similarly. Secondly, it would seek the statification of the victim, offender and community. Thirdly, it would offer legal protection of individuals against unwarranted state action (Johnstone dan Ness, 2007:14). Argumentasi senada dikemukakan oleh Van Ness dan Strong yang mengidentifikasi tiga prinsip lain dalam 
keadilan restoratif. First, justice requires that we work to heal victims, offender and communities that have been injured by crime. Second, victime, offender and communities should have the opportunity for active involvement in the justice process as early and as fully as posible. Third, we must rethink the relative roles and responsibilities of government and community: in promoting justice, gouvernment is responsible for preserving a just order, and community for establishing a just peace (Johnstone dan Ness, 2007:15).

Apabila mengacu pada definisi keadilan restoratif, berikut prinsip-prinsip yang terkandung di dalamnya seperti yang diungkapkan oleh Bazemore dan Walgrave atau oleh Van Ness dan Strong di atas, kita akan mendapati adanya pergeseran paradigma pemidanaan yang semula menitikberatkan pada pembalasan - retributif menjadi pemulihan - restoratif. Karenanya keadilan restoratif berangkat pda beberapa nilai mendasar. First, restorative justice is far more concerned about restortion of the victime and victimized community than with ever more costly punishment of the offender. Second, restorative justice elevates the importance of the victim in the criminal justice process, through incrased involvement, input and services. Third, restorative justice requires that offenders be held directly accountable to the person and/or community that they victimized. Fourth, restorative justice encourges the entire community to be involve in holding the offender accountable and promoting a healing response to the needs of victims and offenders. Fifth, restorative justice places greater emphasis on the offender acceepting responsibility for his or her behavior, and making amends whenever possible, than on the severity of punishment. Sixth, restorative justice recognizes a community responsibility for social condition that contribute to offender behavior (Dressler, 2002:1334).

Dalam mengimplementasikan nilai-nilai tersebut, maka James Dignan menawarkan lima pendekatan (types of restortive justice approach), agar keadilan restoratif berhasil dalam pelaksanaannya. First, court based restitutive and reparative measures (peradilan yang berdasarkan pada ganti kerugian dan pemulihan). Model seperti ini pertama kali diterapkan di Inggris. Second, victime offender mediation programes (program mediasi antara pelaku dan korban kejahatan). Pendekatan ini diimplementasikan di wilayah Amerika Utara. Third, conferencing initiatives (memprakarsai pertemuan perundingan antara pelaku dan korban). Model ini diterapkan di wilayah New Zealand - Selandia Baru (Braithwaite dan Strang, 2002:108). Fourth, community reparation boards and panels (dewan dan panel komunitas masyarakat), diterapkan dalam komunitas masyarakat Skotlandia. Fifth, healing a sentencing circles artinya perundingan pemidanaan, digunakan oleh masyarakat asli Kanada (Dignan, 2005:108)

Berdasarkan uraian tersebut di atas, maka ada beberapa hal yang dapat disimpulkan ketika berbicara tentang keadilan restoratif. Pertama, keadilan restoratif menekankan pada upaya untuk mendorong pelaku agar memikirkan dan memberi solusi (bertanggungjawab) atas kejahatan yang telah dilakukannya kepada korban. Kedua, pihak pertama yang harus dipikirkan ketika terjadi kejahatan adalah korban sebab korbanlah secara langsung merasakan akibat kejahatan tersebut. Ketiga, pelaku dan korban kejahatan selanjutnya dapat duduk bersama untuk mendiskusikan langkah-langkah yang dapat ditempuh guna memulihkan permasalahan yang terjadi (restitutio in integrum). Keempat, negara atau pemerintah harus memastikan bahwa proses pemulihan kepada korban berjalan sesuai kesepakatan bersama antara pelaku dan korban sehingga tidak menimbulkan konflik yang berkepanjangan. Kelima, masyarakat adalah menjadi bagian yang tidak dapat dipisahkan dalam pelaksanaan keadilan restoratif antara pelaku dan korban. Komunitas masyarakat akan berperan penting untuk mendorong dan mendukung penyelesaian masalah dengan menekankan pada pemulihan atau perbaikan akibat tindak pidana yang dilakukan oleh pelaku.

Selain keadilan restoratif (restorative justice) tersebut, dalam literatur masih dikenal beberapa bentuk keadilan yang lain, seperti keadilan masyarakat (community justice) yang dikemukakan oleh Todd R. Clear (Sulivan dan Tifft, 2006:467); keadilan transisional (transitional justice) yang diprakarsai oleh Ruti G. Teitel (Teitel, 2000:163); dan keadilan transformatif (transformative justice) dipelopori oleh M. Key Harris (Sulivan dan Tifft, 2006:555). Diluar bentuk-bentuk keadilan tersebut masih ada dua bentuk keadilan lain yakni 
keadilan korektif (corrective justice) dikemukakan oleh Ernest J. Weinrib (Weinrib, 2012:2); dan keadilan distributif serta keadilan prosedural (distributive justice and prosedural justice) diparkarsai oleh Kjell Tornblom dan Riel Vermunt (2007:1). Bahkan di abad modern ini, sekitar tahun 1971 seorang filosof dari Harvard University bernama John Rawls menuliskan gagasannya dalam sebuah buku dengan judul A Theory of Justice dan Justice as Fairness. Kedua buku ini menjadi literatur yang sangat memadai ketika membahas teori keadilan terutama hubungannya dengan dasar-dasar filsafat politik guna mewujudkan kesejahteraan masyarkat (Rawls, 1999:2). Penjelasan lebih juah inwal bentuk-bentuk keadilan tersebut akan penulis uraikan pada kesempatan yang lain.

\section{Restorative Justice dalam Peradilan Anak di Indonesia}

Ide keadilan restoratif pada dasarnya tidak dapat dipisahkan dari perbuatan pidana atau pelanggaran hukum yang dilakukan oleh seseorang terutama anak. Dalam hal ini seorang anak (di bawah umur) telah melakukan suatu perbuatan yang mana perbuatan tersebut dikategorikan sebagai pelanggaran ketentuan pidana sehingga harus diproseshukum guna pertanggungjawaban pidana. Dengan kata lain anak sedang terlibat dalam suatu kejahatan, biasa juga disebut sebagai delinkuen (Cloword dan Ohlin, 1988:25). Istilah delinkuen berasal dari delinquency (Inggris) yang berarti kenakalan anak atau kenakalan remaja (Soetedjo, 2008:8). Sering pula disebut dengan istilah juvenile delinquency yang artinya adalah sama dengan delinquency. Namun demikian diyakini bahwa delinquency lebih luas cakupannya dibanding juvenil delinquency. Delincuency dapat berupa pelanggaran hukum positif (writen law) tetapi dapat juga hukum yang tidak tertulis (unwriten law). Sedangkan juvenile delinquency dikonotasikan sebagai pelanggaran hukum yang tertulis atau positive law-writen law/rule (Cloword dan Ohlin, 1988:18).

Richard A. Wright dan J. M itchell M iller mendefinisikan juvenile delinquency sebagai any action by someone designated a juvenile (non adult) that would make such a young person subject to action by the juvenile court (Wright dan
Miller, 2005:860). Briyan A. Garner memberi definisi yang lebih luas dengan mengatakan bahwa juvenile delinquency is anti social behavior by a minor; behavior that would be criminally punishable if the actor were an adult but instead is use punished by special laws pertaining only to minorsalso termed delinquen minor (Garner, 2004:884). Ada dua hal yang dapat disimpulkan dari argumentasi yang dikemukakan oleh Richard A. Wright dan J. M itchell Miller serta Briyan A. Garner tersebut. Pertama, juvenile delinquency adalah tindakan melanggar hukum - melawan hukum yang dilakukan oleh anak (bukan orang dewasa) yang kemudian dapat diadili pada pengadilan anak. Kedua, perbuatan itu seharusnya sudah menjadi kejahatan bila dilakukan oleh orang dewasa tetapi karena dilakukan oleh anak maka hanya dianggap sebagai kenakalan anak.

Bertalian dengan itu, Paul W. Tapan kemudian menyebut juvenile delinquency is a person who has been adjudicated as such by a court of proper jurisdiction thought he may be no different, up who are not delinquent (Tapan, 1994:30). Atas argumentasi Tapan ini, maka Romli Atmasamita mengatakan bahwa istilah delinquency tidak identik dengan istilah kenakalan dan istilah juvenile tidak identik dengan istilah anak. Istilah juvenile delinquency lebih luas artinya dari pada istilah kenakalan ataupun istilah anakanak. Romli kemudian menegaskan bahwa lebih tepat menggyunakan istilah kenakalan anak dari pada kejahatan anak-anak. Bila diperhatikan lebih dalam penjelasan Romli tersebut, maka sebetulnya tidak terlalu mempengaruhi hakikat juvenile delinquency sebab telah diakui sejak awal bahwa kenakalan anak dalam literatur disebut sebagai delinquency - delinkuen. Jadi Romli hanya memberi penekanan secara psikologis ihwal pentingnya membedakan perlakuan antar perbuatan jahat yang dilakukan oleh orang dewasa dan anak-anak. Bagi orang dewasa pelanggaran hukum mutatis mutandis disebut sebagai kejahatan sedangkan bagi anak-anak itu adalah kenakalan.

Kembali ke pembahasan tentang restorative justice, ketika seorang anak melakukan pelanggaran hukum (juvenile delinquency) maka anak tersebut akan mengalami proses hukum. Proses tersebut tentunya akan berbeda dengan orang dewasa. Pada saat ini di Indonesia proses peradilan pidana kepada anak diatur melalui Undang-Undang Nomor 
11 Tahun 2012 tentang Sistem Peradilan Pidana Anak. Dalam peraturan a quo memperkenalkan pranata baru peradilan yang disebut dengan diversi dan keadilan restoratif. Diversi diartikan sebagai pengalihan penyelesaian perkara anak dari proses peradilan pidana ke proses di luar peradilan pidana (Pasal 1 angka 7 UU SPPAnak). Sedangkan keadilan restoratif adalah penyelesaian perkara tindak pidana dengan melibatkan pelaku, korban, keluarga, pelaku/korban, dan pihak lain yang terkait untuk bersama-sama mencari penyelsaian yang adil dengan menekankan pemulihan kembali pada keadaan semula, dan bukan pembalasan (Pasal 1 angka 6 UU SPP Anak). Intinya untuk mencapai restorative justice maka dapat ditempuh melalui diversi. Diversi ini bersifat wajib dan dapat dimulai sejak tahap penyidikan, penuntutan hingga tahap pemeriksaan di sidang pengadilan anak (Pasal 7 ayat (1) UU SPP Anak).

Kay Pranis mengusulkan agar pelaksanaan diversi atau keadilan restoratif (restorative justice) dapat terlaksana dengan baik maka perlu ditempuh langkah-langkah berikut: pertama, pelatihan dan informasi tentang keadilan restoratif dan model apa yang dapat diterapkan dalam masyarakat. Kedua, memberikan pendidikan secara mand iri kepada aparat pelaksana keadilan restoratif tentang kondisi masyarakat tempat akan dilasanakannya keadilan restoratif. Ketiga, mengidentifikasi pemimpin yang berkemampuan dan berpengaruh dalam masyarakat sekitarnya melalui informasiinformasi atau catatan-catatan mengenai orang-orang tersebut. Keempat, memahami peran kelompok masyarakat yang memungkinkan dapat diajak bekerjasama. Kelima, menjelaskan tanggungjawab masing-masing pihak yang terlibat dalam pelaksanaan keadilan restoratif (Pranis, 1998:14).

Adapun tujuan diversi meliputi lima hal. Pertama, mencapai perdamaian antara korban dan anak. Kedua, menyelesaikan perkara anak di luar proses peradilan. Ketiga, menghindarkan anak dari proses perampasan kemerdekaan. Keempat, mendorong masyarakat untuk berpartisipasi. Kelima, atau yang terakhir adalah menanamkan rasa tanggungjawab kepada anak (Pasal 6 UU SPP Anak). Syarat agar perkara pidana anak dapat dikenakan diversi ada dua yakni pertama, diancam dengan pidana penjara di bawah tujuh tahun. Kedua, bukan merupakan pengulangan tindak pidana (Pasal 7 ayat (2) UU SPP Anak). Diversi tersebut dilakukan melalui musyawarah dengan melibatkan anak dan orang tua/walinya, korban dan/atau orang tua/walinya pembimbing kemasyarakatan dan pekerja sosial profesional berdasarkan pendekatan keadilan restoratif (Pasal 8 UU SPP Anak). Agar lebih akuntabel maka proses diversi tersebut wajib memperhatikan: kepentingan korban; kesejahteraan dan tanggungjawab anak; menghindarkan stigma negatif; penghindaran pembalasan; keharmonisan masyarakat; kepatutan, kesusilaan dan ketertibaan umum (Pasal 8 ayat (3) UU SPP Anak).

Paling tidak terdapat empat hal yang dapat dipertimbangkan penyidik, penuntut umum dan hakim ketika akan melakukan diversi dalam perkara hukum yang melibatkan anak. Pertama, kategori tindak pidana. Kedua, umur anak. Ketiga, hasil penelitian kemasyarakatan dari BAPAS. Keempat, dukungan lingkungan keluarga dan masyarakat (Pasal 9 ayat (1) UU SPP Anak). Jadi diversi tidak serta merta diberikan dalam perkara hukum yang melibatkan anak tetapi harus berdasarkan empat pertimbangan tersebut. Hal ini sangat penting sebab akan berpengaruh terhadap kondisi psikologi dan sosial anak dan korban beserta keluarganya. Untuk itulah setiap diversi harus mendapatkan persetujuan dari korban dan keluarganya. Namun demikian dalam hal-hal tertentu diversi tersebut tidak membutuhkan lagi persetujuan korban dan keluarganya dengan sejumlah alasan, antara lain: tindak pidana berupa pelanggaran; tindak pidana ringan; tindak pidana tanpa korban; nilai kerugian korban tidak lebih dari nilai upah minimum provinsi setempat (Pasal 9 ayat (2) UU SPP Anak).

Keberhasilan pelaksanaan diversi dalam peradilan anak, juga dipengaruhi oleh rekomendasi dari pembimbing kemasyarakatan berupa: pengembalian kerugian dalam hal ada korban, rehabilitasi medis dan psikososial, penyerahan kembali kepada orang tua atau wali, keikutsertaan dalam pendidikan dan pelatihan di lembaga pendidikan atau LPKS paling lama 3 (tiga) bulan, dan pelayanan masyarakat paling lama 3 (tiga) bulan. Putusan atau hasil kesepakatan diversi dapat berbentuk lima hal (Pasal 10 ayat (2) UU SPP Anak):

1. Mencapai perdamaian antara korban dan anak,

2. Menyelesaikan perkara anak di luar proses peradilan,

3. Menghindarkan anak dari proses perampasan 
kemerdekaan,

4. Mendorong masyarakat untuk berpartisipasi,

5. M enanamkan rasa tanggungjawab kepada anak (Pasal 11 UU SPP Anak).

Adakalanya perkara anak tidak dapat diselesaikan melalui proses diversi, misalnya karena tidak adanya kesepahaman atau kesepakatan antara anak atau keluarganya dengan korban atau ada kesepahaman tetapi tidak dilaksanakan. Dalam hal demikian maka proses peradilan anak dilanjutkan ke persidangan untuk mendapatakan putusan hakim (Pasal 13 UU SPP Anak).

Secara implisit keadilan restoratif juga dapat dijumpai dalam RUU KUHP 2013. M eskipun tidak secara tegas menggunakan nomenklatur keadilan restoratif tetapi pada Pasal 116 RUU, dengan tegas membagi jenis pidana pada anak berupa pidana verbal, pidana dengan syarat, pidana denda dan pidana pembatasan kebebasan. Dalam pidana verbal bentuknya bisa sanksi pidana teguran kerasatau pidana peringatan. Sedangkan pidana dengan syarat dapat berupa: pembinaan di luar lembaga, pidana kerja sosial dan pidana pengawasan. Konstruksi norma yang demikian menunjukan bahwa pembentuk RUU KUHP kelihatannya berusaha mendesain sanksi pidana anak dari yang paling ringan hingga yang paling berat. Sebab pidana pembatasan kebebasan ditempatkan paling akhir dengan syarat yang signifikan, misalnya jika anak terlibat dalam tindak pidana berat atau tindak pidana lain dengan kekerasan. Dengan demikian sanksi pidana berat menjadi upaya terakhir yang dapat diterapkan kepada anak yang melakukan tindak pidana. Pendeknya RUU KUHP pun berusaha mengakomodasi keadilan restoratif dalam konteks tindak pidana yang dilakukan oleh anak.

Kembali pada konsep keadilan restoratif dalam UU SPP Anak, bila melihat prosestercapainya keadilan restoratif yang ditempuh melalui diversi dalam peradilan anak sesuai dengan peraturan a quo, maka ada beberapa hal yang dapat disimpulkan. Pertama, keadilan restoratif yang ditempuh melalui diversi dalam peradilan anak sesungguhnya bukanlah pranata hukum baru dalam peradilan pidana sebab jauh sebelum lahirnya UU sistem peradilan pidana anak, dalam sistem hukum negara lain telah mengenal dan memberlakukan keadilan restoratif seperti yang telah penulis uraikan pada bagian memahami keadilan restoratif. Kedua, secara substantif tidak semua perkara pidana yang dilakukan oleh anak dapat dikenakan diversi atau keadilan restoratif, melainkan harus sesuai dengan persyaratan dalam peraturan a quo. Ketiga, guna mencapai keadilan restoratif peran serta korban atau keluarganya menjadi sangat menentukan. Keempat, konsep diversi atau keadilan restoratif pada dasarnya lebih condong mengakomodasi tujuan pemidanaan yang rehabilitatif-restoratif. Kelima, bila dihubungkan dengan tipe pendekatan restoratif justice yang dikemukakan oleh James Dignan, maka peraturan a quo menggunakan dua pendekatan yakni pendekatan mediasi korban dan pelaku (victim offender mediation) serta pendekatan peradilan yang berdasarkan pada ganti kerugian dan pemulihan (court based restitutive and reparative measure).

\section{KESIMPULAN}

Berdasarkan uraian tersebut di atas, terdapat beberapa hal yang dapat disimpulkan dalam tulisan ini. Pertama, ada pergeseran paradigma pemidanaan dari hukum pidana klasik ke hukum pidana modern. Perubahan tersebut dalam konteks Indonesia dari retributif ke restitoratif, yang dalam pembacaan Muladi disebut sebagai konsep daad-daderstrafrecht atau model keseimbangan kepentingan. Kedua, dalam UU SPP Anak, aroma pergeseran itu sangat jelas terasa. Anak yang melakukan tindak pidana, tidak mutatis mutandis di bawa dalam peradilan pidana tetapi dimungkinkan untuk diselesaikan diluar sidang pengadilan, model ini disebut sebagai diversi. Pendeknya paradigma peradilan pidana, khusus dalam peradilan anak telah bergeser kearah restoratif. Ketiga, dalam penyelesaian perkara anak diupayakan agar pelaku dan keluarganya serta korban dan keluarganya dapat duduk bersama untuk membicarakan penyelesaian maslalah termasuk pemulihan kepada korban (restitution in integrum). Konsep ini dimaknai sebagai keadilan restoratif. Keempat, guna mencapai keadilan restoratif peran serta korban atau keluarganya menjadi sangat menentukan. Kelima, keadilan restoratif hakikatnya adalah memberi hukuman kepada pelaku tetapi hukuman tersebut bersifat mendidik sehingga memberi manfaat baik kepada pelaku maupun korban. Keenam, peraturan a quo menggunakan dua pendekatan yakni pendekatan mediasi korban dan pelaku (victim offender mediation) seperti yang 
diterapkan di Amerika Utara serta pendekatan yang menekankan pada ganti kerugian dan pemulihan (court based restitutive and reparative measure), seperti yang dipraktikan di Inggris.

\section{DAFTAR PUSTAKA}

A tmasasmita, Romli, 2010, Naskah A kademik Rancangan U ndang-U ndang tentang H ukum A cara Pidana, Jurnal Polisi Indonesia, Edisi XIII/Jakarta. , 2010, Sistem Peradilan Pidana K ontemporer, Kencana Pernada M edia G roup, Jakarta. Braithwaite, John, 1998, Restorative Justice, dalam M ichael Tonry, The $\mathrm{H}$ andbook of $\mathrm{C}$ rime and Punishment, $\mathrm{O}$ xford University Press, N ew York.

2002, Restorative Justice and Re sponsive R egulation, $\mathrm{O}$ xford $U$ niversity Press, $\mathrm{N}$ ew York. Cloword, Richard A. and Ohlin, Lloyd E., 1988, Delinquency and $O$ portunity: Theory of D elinquen $G$ angs, The Free Press Collier Macmillan Publishing, N ew York.

Cragg, Wesley, 1992, The Practice of Punishment: Toward a Theory of Restorative Justice, Routledge Taylor and Francis Group, London and New York.

Dennis Sulivan and Larry Tifft, $H$ andbook of Restorative Justice: A G lobal Perspective, Routledge, Taylor \& Francis Group, London and N ew York.

Dignan, James, 2005, U nderstanding V ictim and Restorative Justice, O pen U niversity Press, N ew York.

D ressler, Joshua, 2002, Encyclopedia of $C$ rime and Justice: A bortion-C ruel \& U nusual Punishment (Volume 1), Gale Group Thomson Learning, New York. , 2002, Encyclopedia of C rime and Justice: Juvenile Justice, Juvenile C ourt-R ural $\mathrm{C}$ rime (V olume III), Gale Group Thomson Learning, N ew York.

Emmerson, Ben, Ashworth, Andrew and M acdonald, Alison, 2007, H uman Rights and C riminal Justice (Second Edition), Thomson Sweet and M axwell, Toronto.

Garner, Bryan A, 2004, Blacks Law Dictionary (Eight Edition), West Thomson Publishing, N ew York.

H amzah, Andi, 2012, A sas-A sas H ukum Pidana di Indonesia \& Perkembangannya, PT Sofmedia, Jakarta.

H arris, M. Key, 2006, Transformatif Justice: The Transformation of Restorative Justice, Routledge, Taylor \& Francis Group, London and New York.

H iariej, Eddy O S, A sas L egalitasD alam H ukum A acara Pidana, disampaikan dalam seminar RUU KUHAP dalam tema: Problem dan Prospek RUU Hukum Acara Pidana Tim Pokja N asional, Fakultas H ukum U G M Yogyakarta,
$18 \mathrm{M}$ are 2010.

Johnstone, Gerry and Van Ness, Daniel W., 2007, H andbook of Restorative Justice, W illian Publishing, USA \& $C$ anada.

Joyce, Peter, 2006, C riminal Justice: An Introduction ro C rime and The C riminal Justice System, W illian Publishing, U SA and Canada.

Kadish, Sanford H , 1983, Encyclopedia of C rime and Justice, The Free Press Collier M acmillan Publisher, N ew YorkLondon.

LaFave, Wayne R, 2010, Principles of C riminal Law (Second Edition), West A Thomson Bussines, USA.

Moeljatno, 2008, A sasA sas H ukum Pidana (Edisi Revisi), Rineka Cipta, Jakarta.

M uladi, 1995, K apita Selekta Sistem Peradilan Pidana, Badan Penerbit U niversitas Diponegoro, Semarang.

Packer, H ebert L, 1968, The Limits of the C riminal Sanction, 0 xford U niversity Press.

Strang, H eather and Braithwaite, John, Restorative Justice and Family V iolence, C ambridge U niversity Press, London-UK.

Pranis, Kay, 1998, Engaging The Community in Restorative Justice: Balanced and Restorative Justice, M inesota Press, Florida.

Rawls, John, 1999, A Theory of Justice (R evised Edition), $\mathrm{H}$ arvard U niversity Press, U nited States of America.

Reksodiputro, M arjono, 1993, Sistem Peradilan Pidana Indonesia, M elihat pada K ejahatan dan Penegakan $\mathrm{H}$ ukum dalam Batas-Batas Toleransi, Pidato Pengukuhan Penerimaan Jabatan Guru Besar Tetap dalam IImu Hukum pada Fakultas H ukum U niversitas Indonesia, Jakarta.

Satria, H ariman, 2012, Penerbitan SK PP oleh K ejaksaan D alam Proses Peradilan Pidana, G enta Publishing, Yogyakarta.

$\mathrm{H}$ irsch, Andrew von, Roberts, Julian, Bottoms, Anthony E, Roach, Kent and Schiff, M ara, Restorative Justice \& C riminal Justice: Competing or Reconcilable Paradigms, $\mathrm{H}$ art Publishing, $O$ xford and Portland $O$ regon, England.

Soetedjo, Wagiati, 2008, H ukum Pidana Anak, Refika A ditama, Bandung.

Tapan, Paul W, 1994, Juvenile D elinquency, M cG raw Hill Bokk, N ew Yorktondon.

Teitel, Ruti G ., 2000, Transnational Justice, O xford University Press, New York.

Tornblom, Kjell dan Vermunt, Riel, 2007, Distributive Justice and Procedural Justice: Research and Social A plication, A shgate Publishing Limited, H ampshire-England.

Travis III, Lawrence F, 2012, Introduction C riminal Justice (Seventh Edition), Anderson Publishing, London. 
U trech, E, 1986, H ukum Pidana 1: Suatu Pengantar H ukum Pidana Untuk Tingkat Pelajaran Sarjana M uda H ukum, Suatu Pembahasan Pelajaran U mum, Pustaka Tinta M as, Surabaya.

Weinrib, Ernest J, 2012, Corrective Justice, Oxford U niversity Press, N ew York.

Yeni W idowaty dan Fadia Fitriyanti, M embangun Model Perlindungan $\mathrm{H}$ ukum Terhadap M asyarakat Sebagai K orban Pencemaran Dan/ A tau Perusakan Lingkungan O leh K orporasi D engan Prinsip Restorative Justice, Jurnal M edia Hukum Vol 21, No 1 (2014)

W right, Richard A and Miller, J. Mitchell, 2005, Encyclopedia of C riminology (Volume 2), Routledge Taylor and Francis Group, New York-London. 